\title{
The role of $\alpha_{1}$-adrenoceptors and $5-\mathrm{HT}_{1 \mathrm{~A}}$ receptors in the control of the micturition reflex in male anaesthetized rats
}

\author{
${ }^{1,3}$ Rachel K. Conley (née Snowball), ${ }^{2}$ Timothy J. Williams, ${ }^{2}$ Anthony P.D.W. Ford \& \\ *,1 Andrew G. Ramage
}

${ }^{1}$ Department of Pharmacology, University College London, Royal Free Campus, Rowland Hill Street, Hampstead, London, NW3 2PF and ${ }^{2}$ Roche Biosciences, MIS R2/101, 3401 Hillview Avenue, Palo Alto, California, CA 94304, U.S.A.

1 The effects of the $\alpha_{1}$-adrenoceptor antagonists doxazosin $\left(0.1-2 \mathrm{mg} \mathrm{kg}^{-1}\right)$, RS-100329 $\left(\alpha_{1 \mathrm{~A}}\right.$; $0.01-1 \mathrm{mg} \mathrm{kg}^{-1}$ ), RS-513815 (Ro 151-3815, $\left.\alpha_{1 \mathrm{~B}} ; 0.3-3 \mathrm{mg} \mathrm{kg}^{-1}\right)$ and BMY $7378\left(\alpha_{1 \mathrm{D}} ; 0.1-\right.$ $\left.1 \mathrm{mg} \mathrm{kg}^{-1}\right)$, the 5-HT $1 \mathrm{~A}$ receptor agonist, 8-OH-DPAT $\left(0.03-0.3 \mathrm{mg} \mathrm{kg}^{-1}\right)$ and antagonist WAY$100635\left(0.03-0.3 \mathrm{mg} \mathrm{kg}^{-1}\right)$ were investigated (i.v.) on the 'micturition reflex' in the urethane anaesthetized male rat.

2 Reflex-evoked urethra contractions were most sensitive to the inhibitory action of RS-100329, followed by doxazosin, BMY 7378 and WAY-100635 and then RS-513815. The maximum inhibition was $66,63,54,46$ and $22 \%$ at doses of $0.3,0.5,0.3,0.3$ and $3 \mathrm{mg} \mathrm{kg}^{-1}$ respectively.

3 BMY 7378 and 8-OH-DPAT decreased, while WAY-100635 increased, the pressure threshold to induce bladder contraction. WAY-100635 $\left(0.01 \mathrm{mg} \mathrm{kg}^{-1}\right)$ blocked the effects of BMY 7378 $\left(1 \mathrm{mg} \mathrm{kg}^{-1}\right)$ on bladder pressure and volume threshold.

4 Doxazosin, RS-100329 and BMY 7378 had a similar potency in inducing a fall in arterial blood pressure while WAY-100635 only caused a fall at the highest dose.

5 Therefore, reflex-evoked urethral contraction involves the activation of $\alpha_{1 \mathrm{~A} / 1 \mathrm{D}}$-adrenoceptors, as BMY 7378 and RS-100329 are similarly potent in attenuating this effect. The ability of WAY100635 to attenuate this contraction may suggest that 5- $\mathrm{HT}_{1 \mathrm{~A}}$ receptors are also involved. However, as this inhibition occurred at the highest dose of WAY-100635, which also caused a fall in arterial blood pressure; this effect is considered to be due to blockade of $\alpha_{1}$-adrenoceptors not 5 -HT $1 \mathrm{~A}$ receptors. Nevertheless the initiation of the 'micturition reflex' involves the activation of $5-\mathrm{HT}_{1 \mathrm{~A}}$ receptors.

British Journal of Pharmacology (2001) 133, $61-72$

Keywords: Micturition; bladder and urethral tone; blood pressure; $\alpha_{1}$-adrenoceptors; 5 -HT HA $_{1 \mathrm{~A}}$ receptors; RS-100329; RS513815; BMY 7378; 8-OH-DPAT; WAY-100635

Abbreviations: HR, heart rate; MAP, mean arterial blood pressure; NMB, neuromuscular block

\section{Introduction}

Micturition and continence depend on co-ordinated, and reciprocal, activity in the detrusor muscle of the bladder and the urethral smooth muscle and sphincter. This coordination is mediated by sympathetic, parasympathetic and somatic nerve pathways and is integrated by control centres in the spinal cord, pons and forebrain. As such, several neurotransmitters regulate lower urinary tract function, acting at both peripheral and central sites. One of the major neurotransmitters involved in mediating these actions is noradrenaline (see Anderson, 1993). Activation of noradrenergic pathways contracts the urethra and bladder neck during continence and at the onset of micturition. Evidence suggests that this contraction is mediated by $\alpha_{1}$ adrenoceptors. For example, $\alpha_{1}$-adrenoceptor agonists increase intraurethral pressure and contract the isolated urethra (Taniguchi et al., 1996; Nishimatsu et al., 1999) while antagonists at the $\alpha_{1}$-adrenoceptor, such as doxazosin

\footnotetext{
*Author for correspondence; E-mail: a.ramage@ucl.ac.uk

${ }^{3}$ Current address: Department of Pharmacology, Merck Sharp \& Dohme Research Laboratories, Neuroscience Research Centre, Terlings Park, Harlow, Essex CM20 2QR, U.K.
}

and prazosin, inhibit contractions of the prostate and urethra induced by phenylephrine or hypogastric nerve stimulation in the anaesthetized rat, rabbit and dog (Imagawa et al., 1989a,b; Kenny et al., 1994; Guilmard et al., 1996; Suzuki et al., 2000). In conscious rats, $\alpha_{1^{-}}$ adrenoceptor antagonists reduce baseline urethral pressure (Martin et al., 1995; 1997) and, in the conscious dog, doxazosin, terazosin and tamsulosin block increases in urethral pressure induced by phenylephrine (Brune et al., 1996). $\alpha_{1}$-adrenoceptor antagonists have also been shown to reduce central sympathetic tone to the lower urinary tract (Ramage \& Wyllie, 1995; see De Groat et al., 1999). Furthermore, $\alpha_{1}$-adrenoceptor antagonists are used in the clinic to reduce prostatic and urethral pressures in benign prostatic hyperplasia (see Jønler et al., 1994; Chapple, 1996). Currently $\alpha_{1}$-adrenoceptors have been divided into three recognizable subtypes $\left(\alpha_{1 \mathrm{~A}}, \alpha_{1 \mathrm{~B}}\right.$ and $\alpha_{1 \mathrm{D}}$ : see Hieble et al., 1995), however the importance of these different $\alpha_{1}$ adrenoceptor subtypes in the overall control of micturition has not yet been established.

To determine the role of these different subtypes in the control of micturition the following antagonists were 
chosen: doxazosin a non-selective $\alpha_{1}$, RS-100329 a selective $\alpha_{1 \mathrm{~A}}$ (Williams et al., 1999), RS-513815 (Ro 151-3815) a selective $\alpha_{1 \mathrm{~B}}\left(\mathrm{pK}_{\mathrm{i}} 9.17 \pm 0.14, n=4\right.$, c.f. $\alpha_{1 \mathrm{~A}} 7.39 \pm 0.14$ and $\alpha_{1 \mathrm{D}} 6.85 \pm 0.05$, unpublished data from T.J. Williams using the method described by Williams et al. (1999)) and BMY 7378, a selective $\alpha_{1 \mathrm{D}}$ adrenoceptor antagonist (Goetz et al., 1995). However, BMY 7378 is known to be a partial agonist at $5-\mathrm{HT}_{1 \mathrm{~A}}$ receptors (Yocca et al., 1987). In this respect, it has been shown that $5-\mathrm{HT}_{1 \mathrm{~A}}$ receptors play a role in the control of bladder contractions (Lecci et al., 1992). This is consistent with the demonstration that central 5-hydroxtryptaminergic pathways (De Groat et al., 1979; McMahon \& Spillane, 1982; Morrison \& Spillane, 1982; Espey et al., 1998) are involved in the control of bladder reflexes and the concept that $5-\mathrm{HT}_{1 \mathrm{~A}}$ receptors are important in the reflex control of parasympathetic outflow (see Ramage, 2000). Therefore, the effects of the selectve 5$\mathrm{HT}_{1 \mathrm{~A}}$ receptor agonist 8-OH-DPAT (Middlemiss \& Fozard, 1983) and antagonist WAY-100635 (Forster et al., 1995) were also examined on the micturition reflex in urethane anaesthetized male rats based on a method developed by M. Fraser (see Kakizaki et al., 1997; Wibberley, 2001) which allows simultaneous measurements of bladder and urethral changes during this reflex. Preliminary accounts of the results have been published in abstract form (Snowball et al., 1999; 2000).

\section{Methods}

The experiments were carried out under the Animals (Scientific Procedures) Act, 1986. After completion of experiments, animals were killed by an overdose of pentobarbitone sodium (i.v.).

\section{General preparation}

Experiments were carried out in 125 male anaesthetized spontaneously breathing Sprague Dawley rats (300-390 g). Anaesthesia was induced and maintained during initial surgical procedures, with isoflurane in oxygen $3.5 \%$ reduced to $1 \%$ as necessary). The femoral vein, femoral artery and trachea were cannulated to permit intravenous injection of drugs, measurement of arterial blood pressure (and heart rate) and maintenance of a patent airway. Isoflurane administration was discontinued and anaesthesia was maintained for the remainder of the experiment with i.v. injections of urethane $(25 \%$ solution, initial dose of $1.0-$ $1.2 \mathrm{~g} \mathrm{~kg}^{-1}$, see Maggi et al., 1986). Depth of anaesthesia was assessed by the stability of blood pressure and heart rate, and by an absence of limb withdrawal in response to paw pinch. In preparations where neuromuscular blockade was produced by $\alpha$-bungarotoxin $\left(0.4 \mathrm{mg} \mathrm{kg}^{-1}\right.$, i.v. $)$, depth of anaesthesia was assessed by stability of cardiovascular variables and by an absence of cardiovascular response to paw pinch. Supplementary doses of urethane $\left(0.1 \mathrm{~g} \mathrm{~kg}^{-1}\right.$, i.v.) were given where necessary. In some experiments, a cannula was inserted into the descending aorta via the other femoral artery to allow close arterial injections of tyramine. Body core temperature was maintained between 36 and $38^{\circ} \mathrm{C}$ by feedback from a thermosensor in the rectum to a heated blanket.

\section{Measurement of bladder and urethral pressures}

The ureters were isolated at the level of the kidney through retroperitoneal incisions. Each ureter was cannulated proximal to the kidney in order to prevent urine flow into the bladder. The rat's head was secured in a stereotaxic frame that was tilted at an angle of $10-20^{\circ}$ so that the body could lie in a supine position. This ensured that intravesical bladder pressure was not affected by the weight of the rat. The urinary bladder was exposed and two cannulae were inserted into the lumen of the bladder through an incision in the bladder dome. One of the cannulae allowed the measurement of intraluminal pressure and the other permitted infusion of saline into the bladder. A third cannula was inserted through the bladder dome into the proximal urethra. This cannula comprised an outer tube (outer diameter: $1.52 \mathrm{~mm}$, inner: $0.86 \mathrm{~mm}$ ), through which saline was perfused, and an inner tube (outer diameter: $0.80 \mathrm{~mm}$, inner: $0.40 \mathrm{~mm}$ ), through which urethral pressure was measured, encased in an Eppendorf pipette tip which was positioned in the neck of the bladder (see Kakizaki et al., 1997; Figure 1). The urethra was perfused at a constant rate $\left(0.08 \mathrm{ml} \mathrm{min}^{-1}\right)$ so that changes in urethral pressure reflected changes in resistance to the flow of saline. The three cannulae were secured with a purse-string suture around the bladder dome. Surgical preparation was followed by a stabilization period of $30 \mathrm{~min}$. During stabilization, inspired air was enriched with oxygen $\left(0.05-0.101 \mathrm{~min}^{-1}\right)$ and blood gases and $\mathrm{pH}$ were monitored and maintained between $90-130 \mathrm{mmHg} \mathrm{P}_{\mathrm{O}_{2}}, 40-$ $50 \mathrm{mmHg} \mathrm{P}_{\mathrm{CO}_{2}}$ and $\mathrm{pH} 7.3-7.4$.

\section{Experimental protocol}

Saline was infused into the bladder at $0.05 \mathrm{ml} \mathrm{min}^{-1}$ (the maximal physiological rate of diuresis in the cat, see Klevmark, 1974). The saline infusion was discontinued after three consecutive bladder contractions of the same amplitude. Bladder and urethral activities were monitored for a further 5 min before the saline was drained from the bladder through the bladder infusion cannula. This first infusion was carried out to 'test and prime' the system and was followed by a delay of $20 \mathrm{~min}$. A second infusion was carried out to evoke a 'control' reflex. Again, the saline infusion was discontinued after three consecutive bladder contractions of the same amplitude. Bladder and urethral activities were monitored for a further $5 \mathrm{~min}$ before the saline was drained from the bladder. After $5 \mathrm{~min}, 0.05-0.35 \mathrm{ml}$ of $0.04 \mathrm{M}$ lactic acid or test drug (in $0.04 \mathrm{M}$ lactic acid) was injected i.v. and $5 \mathrm{~min}$ later a distension-induced bladder reflex was evoked as described above. In the tyramine experiments, two injections were given i.a. via the femoral artery $20 \mathrm{~min}$ apart followed $15 \mathrm{~min}$ after the last injection by an injection of test substance i.v. After a further $5 \mathrm{~min}$, another i.a. injection of tyramine was given. When neuromuscular blockade was induced, animals were left for $30 \mathrm{~min}$ after the administration of $\alpha$-bungarotoxin for blood gases and $\mathrm{pH}$ to stabilize before tyramine was given as described above.

\section{Analysis of data}

Reflex changes in bladder and urethral pressure were analysed off-line using Spike 2 (CED). Reflexes before and 

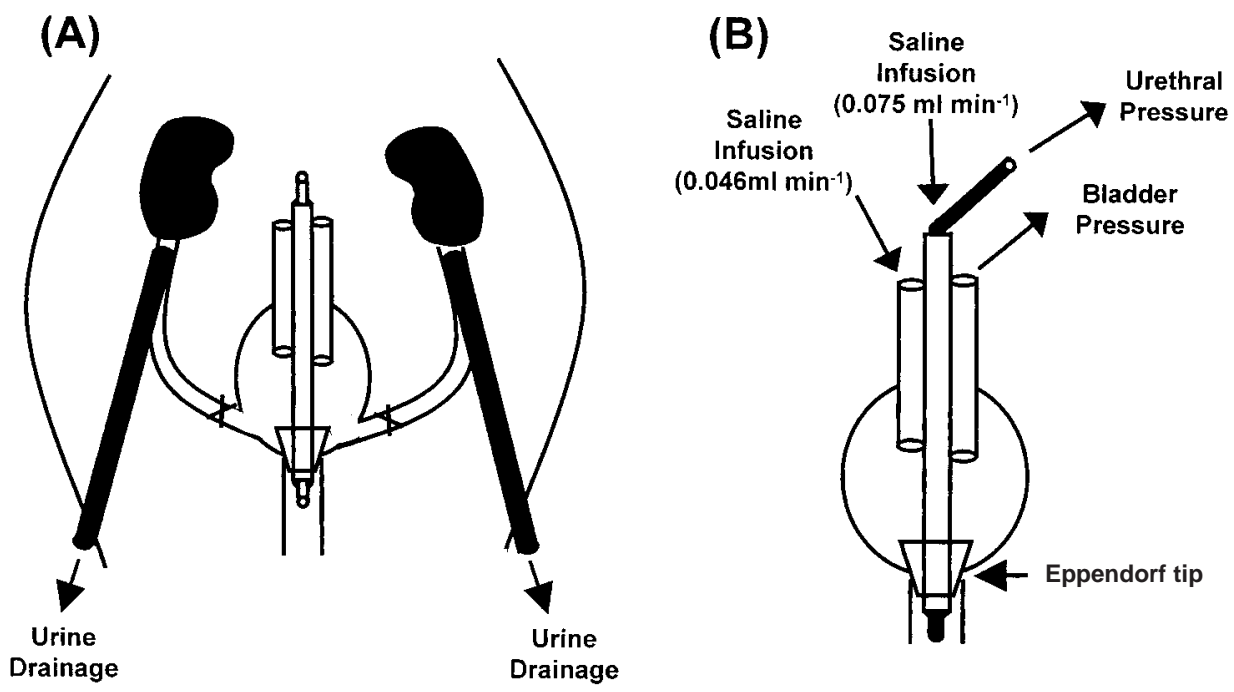

Figure 1 Schematic representation of the experimental method used for both evoking and measuring changes in bladder and urethral pressures. (A) Shows the overall preparation with the ureters tied and cut at the level of the bladder and cannulated at the level of the kidneys plus the position of the cannulae for evoking and recording of changes in bladder and urethral pressures. (B) Is an expanded diagram of the double lumen cannula embedded in an eppendorf tip which is wedged against the bladder neck plus the two additional cannulae inserted into the bladder which allow the measurement of intravesical bladder pressure as well as saline infusion to evoke the micturition reflex.

after the test solution i.v. were analysed. Analysis of each reflex focused on the volume and pressure thresholds required to initiate the first contraction of the bladder that was discernible from background activity and the three consecutive reflex-evoked bladder contractions of similar amplitude that immediately preceded the end of the infusion. In addition, the urethral responses that accompanied these contractions were measured. Although urethral relaxations were observed, most of the urethral responses that were associated with contractions of the bladder were contractions. Thus, only urethral contractions were analysed. The following bladder and urethral variables were measured: (1) the volume and pressure threshold to initiate the first bladder contraction; (2) the mean amplitude (peak-base) and duration of the three regular bladder contractions; and (3) the mean amplitude and duration of the urethral responses associated with the three regular bladder contractions. The following baseline measurements were made: (1) urethral pressure and background activity (mean value measured over $3 \mathrm{~min}$ ); and (2) mean arterial pressure and heart rate (measured over $30 \mathrm{~s}$, 2 min before the beginning of the infusion to evoke the control reflex). Changes in baseline variables caused by the test substances were measured 2 min before the test (second) reflex and compared to the values obtained 2 min before the control reflex. It should be noted that the control reflex did not affect baseline values. Some test drugs induced bursts of high amplitude, high frequency oscillations in urethral pressure (e.g. see Figure 5). This effect was quantified by measuring the number of bursts induced over $60 \mathrm{~min}$ after the test drug.

Changes in these variables caused by drug or vehicle were measured as a percentage of the control values and compared using a Student's unpaired $t$-test. Values of $P<0.05$ were considered significant.

\section{Drugs and solutions}

Drugs and chemicals were obtained from the following sources: urethane, $\alpha$-bungarotoxin, tyramine $\mathrm{HCl}$, 8-hydroxy-2-(di-N-propylamino) tetralin $\mathrm{HBr}$ (8-OH-DPAT), BMY 7378 (8-[2-[4-(2-methoxyphenyl)-1-piperazinyl]ethyl]-8-azaspiro[4,5]decane-7,9-dione. 2HCl) and WAY-100635 (N-[2-[4(2-methoxyphenyl) -1-piperazinyl] ethyl]-N- (2-pyridinyl)cyclohexanecarboxamide trihydrochloride) from Sigma Aldrich Chemical Co., Poole, Dorset, U.K.; pentobarbitone sodium from Rhône Mérieux Ltd, Harlow, Essex, U.K.; isoflurane from Abbott Labs, Queenborough, Kent, U.K. Doxazosin mesylate and prazosin base were gifts from Pfizer Central Research, Kent, U.K. RS100329 (3-(3-\{4[Fluro-2-(2,2,2trifluoroethoxy) -phenyl] -piperazin-lyl $\}$-propyl) -5-methyl-1Hpyrimidine-2,4-dione monohydrochloride monohydrate) and RS-513815 (Ro 151-38154; 4-(2-Naphthalen-1-yl-5-oxooxazol-4-ylidenemethyl)-N-phenyl-piperazine-1-carboxamidine hydrochloride) were synthesized at Roche Bioscience at Palo Alto, CA, U.S.A. Agents were given i.v. as their respective salts, with the exception of tyramine which was given i.a.

\section{Results}

\section{Baseline values}

Control micturition reflex Infusion of saline into the bladder in 117 male rats caused distension of the bladder, which in turn evoked the 'micturition reflex', characterized by the appearance of rhythmic bladder contractions of $31 \pm 1 \mathrm{mmHg}$ (e.g. see Figure 2). These contractions had a mean duration 

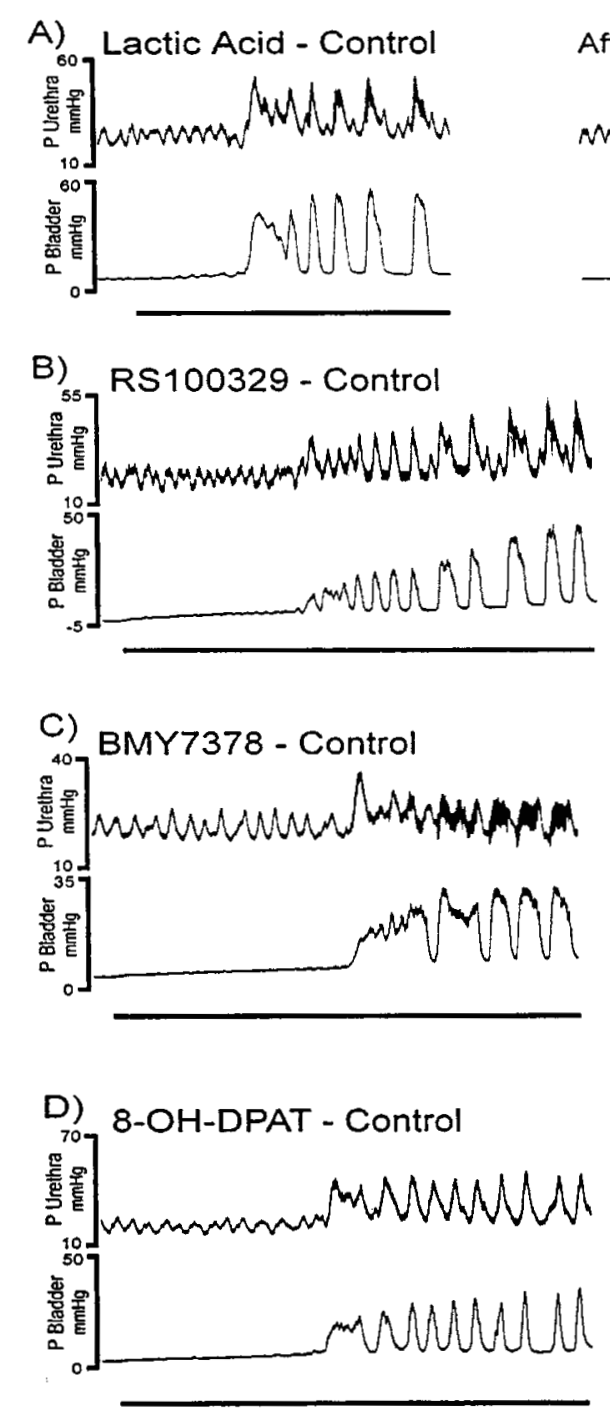

After $0.04 \mathrm{M}$ i.v.
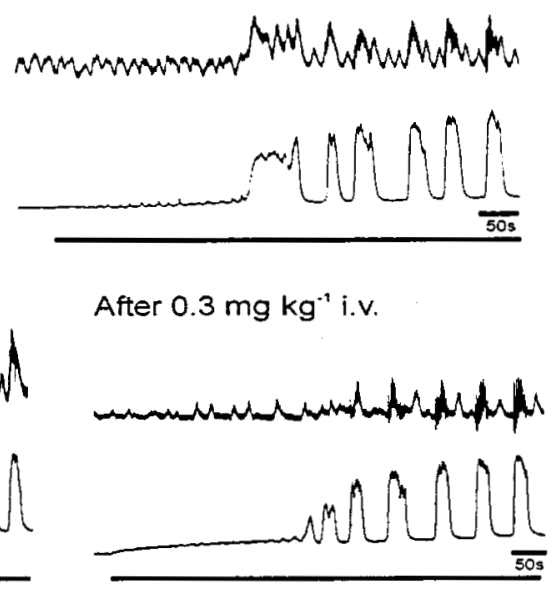

After $0.3 \mathrm{mg} \mathrm{kg}^{-1}$ i.v.
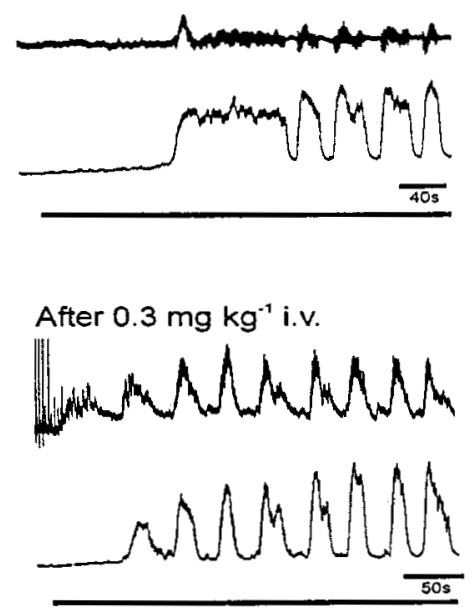

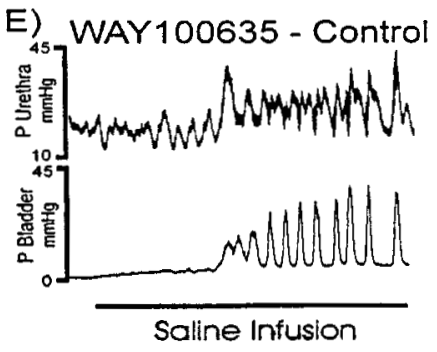

After $0.1 \mathrm{mg} \mathrm{kg}^{-1}$ i.v.
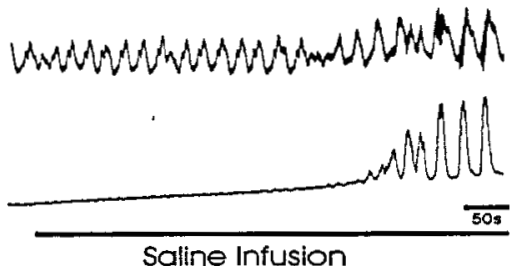

Figure 2 Urethane anaesthetized male rats: traces showing changes in bladder and urethral pressures during intravesical infusions of saline before (Control) and after i.v. injections of (A) lactic acid, (B) $0.3 \mathrm{mg} \mathrm{kg}$-1 of RS-100329, (C) $0.3 \mathrm{mg} \mathrm{kg}^{-1}$ of BMY 7378 , (D) $0.3 \mathrm{mg} \mathrm{kg}^{-1}$ of $8-\mathrm{OH}-\mathrm{DPAT}$ and (E) $0.1 \mathrm{mg} \mathrm{kg}^{-1}$ of WAY-100635. The length of line under each trace represents the duration of the intravesical infusions.

of $30 \pm 2 \mathrm{~s}$. The mean bladder pressure threshold to evoke the micturition reflex was $8 \pm 0.3 \mathrm{mmHg}$, which was reached when $0.15 \pm 0.01 \mathrm{ml}$ of saline had been infused into the bladder. Each rhythmic bladder contraction was accompanied by an increase in urethral pressure of $19 \pm 1 \mathrm{mmHg}$ that continued for $30 \pm 2 \mathrm{~s}$ before returning to baseline (see Figure 2). Occasionally, during these bladder contractions, the rise in urethral pressure was associated with high frequency low amplitude oscillations in urethral pressure. The mean data for the control reflex in each experimental group are shown in Table 1. Reflex bladder contractions were often accompanied by small increases in MAP and HR, which were not analysed. The combined $(n=125)$ baseline mean urethral pressures, urethral slow wave background activity (see Figure 2), MAP and heart rate were $22 \pm 0.6 \mathrm{mmHg}, 3.6 \pm 0.1$ waves $\mathrm{min}^{-1}$, $112 \pm 2 \mathrm{mmHg}, 385 \pm 4$ beats $\mathrm{min}^{-1}$, respectively. The mean baseline data for individual experimental groups are shown in Table 2 . 
Table 1 Baseline values of control 'initial' reflex-evoked changes in bladder and urethral pressures caused by intravesical infusion of saline for each experimental group in urethane anaesthetized male rats. All drugs and solutions were given i.v.

\begin{tabular}{|c|c|c|c|c|c|c|c|}
\hline & & & 'Initic & $x$ baseline & & & \\
\hline & & Bladd & esholds & Rhythmic bl & ontractions & Urethra & tractions \\
\hline $\begin{array}{l}\text { Experimental } \\
\text { group }\end{array}$ & $\mathrm{n}$ & $\begin{array}{l}\text { Pressure } \\
(\mathrm{mmHg})\end{array}$ & $\begin{array}{l}\text { Saline } \\
\text { Volume } \\
(\mathrm{ml})\end{array}$ & $\begin{array}{l}\text { Amplitude } \\
\text { (mmHg) }\end{array}$ & $\begin{array}{l}\text { Duration } \\
\text { (s) }\end{array}$ & $\begin{array}{l}\text { Amplitude } \\
\text { (mmHg) }\end{array}$ & $\begin{array}{l}\text { Duration } \\
\text { (s) }\end{array}$ \\
\hline Lactic acid & & & & & & & \\
\hline $0.3 \mathrm{ml}$ & 7 & $8.9 \pm 1.6$ & $0.11 \pm 0.02$ & $31.2 \pm 2.3$ & $29.3 \pm 8.1$ & $18.9 \pm 1.7$ & $28.5 \pm 7.0$ \\
\hline Doxazosin & & & & & & & \\
\hline $0.1 \mathrm{mg} \mathrm{kg}^{-1}$ & 5 & $6.5 \pm 0.4$ & $0.17 \pm 0.05$ & $30.9 \pm 6.5$ & $39.0 \pm 6.5$ & $19.8 \pm 4.0$ & $42.5 \pm 8.3$ \\
\hline $0.5 \mathrm{mg} \mathrm{kg}^{-1}$ & 5 & $6.6 \pm 0.6$ & $0.21 \pm 0.06$ & $26.7 \pm 6.0$ & $23.8 \pm 4.9$ & $14.8 \pm 1.1$ & $23.7 \pm 4.7$ \\
\hline $1.0 \mathrm{mg} \mathrm{kg}^{-1}$ & 5 & $6.8 \pm 1.6$ & $0.15 \pm 0.07$ & $30.7 \pm 6.0$ & $39.9 \pm 8.4$ & $19.3 \pm 4.7$ & $38.8 \pm 8.5$ \\
\hline $2.0 \mathrm{mg} \mathrm{kg}^{-1}$ & 5 & $7.4 \pm 1.7$ & $0.28 \pm 0.13$ & $31.7 \pm 6.8$ & $22.1 \pm 2.8$ & $19.2 \pm 2.3$ & $17.7 \pm 1.5$ \\
\hline RS100329 & & & & & & & \\
\hline $0.01 \mathrm{mg} \mathrm{kg}^{-1}$ & 5 & $9.6 \pm 1.2$ & $0.28 \pm 0.11$ & $24.2 \pm 3.6$ & $35.0 \pm 9.8$ & $23.5 \pm 3.5$ & $39.2 \pm 10.4$ \\
\hline $0.03 \mathrm{mg} \mathrm{kg}^{-1}$ & 5 & $9.3 \pm 0.9$ & $0.18 \pm 0.06$ & $31.6 \pm 3.5$ & $33.5 \pm 15.1$ & $21.7 \pm 1.9$ & $34.7 \pm 14.5$ \\
\hline $0.1 \mathrm{mg} \mathrm{kg}^{-1}$ & 5 & $9.4 \pm 0.7$ & $0.08 \pm 0.03$ & $30.9 \pm 4.2$ & $38.9 \pm 9.2$ & $13.9 \pm 4.0$ & $35.9 \pm 10.2$ \\
\hline $0.3 \mathrm{mg} \mathrm{kg}^{-1}$ & 4 & $4.8 \pm 1.0$ & $0.09 \pm 0.04$ & $29.4 \pm 2.9$ & $21.5 \pm 3.9$ & $17.0 \pm 3.1$ & $21.3 \pm 3.4$ \\
\hline $1.0 \mathrm{mg} \mathrm{kg}^{-1}$ & 4 & $10.4 \pm 0.3$ & $0.18 \pm 0.05$ & $24.5 \pm 3.4$ & $35.9 \pm 18.6$ & $23.1 \pm 2.7$ & $36.2 \pm 18.4$ \\
\hline RS513815 & & & & & & & \\
\hline $0.3 \mathrm{mg} \mathrm{kg}^{-1}$ & 3 & $10.8 \pm 1.7$ & $0.25 \pm 0.13$ & $24.3 \pm 2.4$ & $31.4 \pm 7.5$ & $27.0 \pm 6.6$ & $30.3 \pm 7.5$ \\
\hline $1.0 \mathrm{mg} \mathrm{kg}^{-1}$ & 3 & $8.0 \pm 0.4$ & $0.19 \pm 0.08$ & $34.2 \pm 9.9$ & $30.5 \pm 7.9$ & $17.8 \pm 3.1$ & $33.5 \pm 10.7$ \\
\hline $3.0 \mathrm{mg} \mathrm{kg}^{-1}$ & 3 & $8.0 \pm 1.0$ & $0.07 \pm 0.04$ & $41.0 \pm 3.0$ & $24.3 \pm 2.5$ & $17.2 \pm 1.3$ & $20.8 \pm 4.2$ \\
\hline BMY 7378 & & & & & & & \\
\hline $0.03 \mathrm{mg} \mathrm{kg}^{-1}$ & 5 & $8.4 \pm 1.1$ & $0.10 \pm 0.03$ & $27.4 \pm 4.1$ & $21.6 \pm 1.9$ & $17.5 \pm 2.5$ & $22.7 \pm 3.2$ \\
\hline $0.1 \mathrm{mg} \mathrm{kg}^{-1}$ & 5 & $8.7 \pm 1.5$ & $0.13 \pm 0.04$ & $28.8 \pm 3.9$ & $26.8 \pm 6.7$ & $15.5 \pm 1.5$ & $26.0 \pm 7.4$ \\
\hline $0.3 \mathrm{mg} \mathrm{kg}^{-1}$ & 5 & $5.8 \pm 1.3$ & $0.06 \pm 0.03$ & $35.9 \pm 5.7$ & $26.0 \pm 3.1$ & $18.1 \pm 3.8$ & $28.8 \pm 3.7$ \\
\hline $1.0 \mathrm{mg} \mathrm{kg}^{-1}$ & 5 & $9.7 \pm 0.7$ & $0.25 \pm 0.07$ & $32.9 \pm 6.3$ & $23.8 \pm 4.6$ & $20.5 \pm 2.4$ & $22.5 \pm 4.5$ \\
\hline 8-OH-DPAT & & & & & & & \\
\hline $0.03 \mathrm{mg} \mathrm{kg}^{-1}$ & 5 & $8.1 \pm 0.4$ & $0.05 \pm 0.03$ & $41.8 \pm 4.6$ & $26.4 \pm 3.1$ & $16.5 \pm 1.5$ & $26.0 \pm 3.2$ \\
\hline $0.1 \mathrm{mg} \mathrm{kg}^{-1}$ & 5 & $7.7 \pm 1.6$ & $0.09 \pm 0.04$ & $29.0 \pm 2.0$ & $27.1 \pm 6.6$ & $12.3 \pm 1.2$ & $30.0 \pm 9.8$ \\
\hline $0.3 \mathrm{mg} \mathrm{kg}^{-1}$ & 6 & $8.5 \pm 1.1$ & $0.10 \pm 0.01$ & $35.1 \pm 2.2$ & $46.6 \pm 9.6$ & $26.3 \pm 2.6$ & $50.6 \pm 10.0$ \\
\hline WAY 100635 & & & & & & & \\
\hline $0.01 \mathrm{mg} \mathrm{kg}^{-1}$ & 4 & $8.6 \pm 0.8$ & $0.27 \pm 0.09$ & $32.1 \pm 5.4$ & $33.1 \pm 9.6$ & $20.1 \pm 3.9$ & $35.1 \pm 10.3$ \\
\hline $0.03 \mathrm{mg} \mathrm{kg}^{-1}$ & 4 & $7.6 \pm 0.5$ & $0.19 \pm 0.04$ & $35.6 \pm 5.8$ & $20.7 \pm 1.7$ & $19.6 \pm 3.1$ & $21.1 \pm 1.6$ \\
\hline $0.1 \mathrm{mg} \mathrm{kg}^{-1}$ & 5 & $5.8 \pm 0.5$ & $0.10 \pm 0.02$ & $34.3 \pm 2.3$ & $22.7 \pm 2.3$ & $19.9 \pm 2.4$ & $24.8 \pm 4.0$ \\
\hline $0.3 \mathrm{mg} \mathrm{kg}^{-1}$ & 5 & $5.7 \pm 1.3$ & $0.08 \pm 0.05$ & $25.8 \pm 4.0$ & $21.7 \pm 2.4$ & $16.5 \pm 2.8$ & $19.7 \pm 3.4$ \\
\hline WAY 100635 & & & & & & & \\
\hline $\begin{array}{l}0.01 \mathrm{mg} \mathrm{kg}^{-1} \\
+\mathrm{BMY} 7378 \\
1.0 \mathrm{mg} \mathrm{kg}^{-1}\end{array}$ & 4 & $10.1 \pm 1.4$ & $0.20 \pm 0.03$ & $25.7 \pm 1.8$ & $41.2 \pm 10.1$ & $27.3 \pm 3.9$ & $43.9 \pm 9.7$ \\
\hline
\end{tabular}

Effect of the $\alpha_{1}$-adrenoceptor antagonists, doxazosin, $R S-100329, R S-513815$ and BMY 7378 on the micturition reflex

Urethra Doxazosin (i.v., $0.1-2 \mathrm{mg} \mathrm{kg}^{-1} ; n=5$ ) significantly $(P<0.05)$, when compared with vehicle $(0.04 \mathrm{M}$ lactic acid $)$, attenuated the reflex-induced urethral contractions at all doses, causing a maximum inhibition of $63 \pm 7 \%$ at $0.5 \mathrm{mg} \mathrm{kg}^{-1}$ (Figure 3). Both RS-100329 (0.01-1 mg kg-1; $n=4-5)$ and BMY $7378\left(0.1-1 \mathrm{mg} \mathrm{kg}^{-1} ; n=5\right)$ significantly attenuated the reflex-induced urethral contractions, causing a maximum inhibition of $66 \pm 9$ and $54 \pm 3 \%$ respectively at $0.3 \mathrm{mg} \mathrm{kg}^{-1}$. Traces showing the effect of RS-100329 and BMY 7378 at the dose $0.3 \mathrm{mg} \mathrm{kg}^{-1}$ are shown in Figure 2 . RS- 100329 also attenuated the contractions at doses of 0.03 and $0.1 \mathrm{mg} \mathrm{kg}^{-1}$ by $27 \pm 11$ and $28 \pm 14 \%$ respectively, although only the inhibition at $0.03 \mathrm{mg} \mathrm{kg}^{-1}$ was significant. RS-513815 $\left(0.3-3 \mathrm{mg} \mathrm{kg}^{-1} ; n=3\right)$ only caused a significant attenuation of these contractions at $3 \mathrm{mg} \mathrm{kg}^{-1}$ of $22 \pm 8 \%$. A dose response curve showing the effect of these antagonists on reflex urethral contractions is shown in Figure 3. None of these antagonists significantly affected the duration of the contractions, except doxazosin, which significantly increased the duration at the high dose of $2 \mathrm{mg} \mathrm{kg}^{-1}$ by $315 \pm 82 \mathrm{~s}$.
All antagonists caused a fall in baseline urethral pressure reaching a maximum of $19 \pm 5 \%$ for doxazosin at $2 \mathrm{~m} \mathrm{~kg}^{-1}$, of $23 \pm 5 \%$ for RS- 100329 at $1 \mathrm{mg} \mathrm{kg}{ }^{-1}$, of $12 \pm 5 \%$ for RS513815 at $0.3 \mathrm{mg} \mathrm{kg}^{-1}$ and of $27 \pm 6 \%$ for BMY 7378 at $1 \mathrm{mg} \mathrm{kg}^{-1}$. Although these changes were dose related, except those evoked by RS-513815, the dose response curve was very shallow (Figure 3). Background slow wave activity in the urethra was abolished by doxazosin at $0.5 \mathrm{mg} \mathrm{kg}^{-1}$ and also by RS-100329 and BMY 7378 at $1 \mathrm{mg} \mathrm{kg}^{-1}$ but not by RS513815 (data not illustrated). Both doxazosin and RS-100329 caused the appearance of bursts of fast high amplitude oscillations in baseline urethral pressure (see Figure 4). The appearance of these bursts was dose related, occurring at 0.01 and $0.03 \mathrm{mg} \mathrm{kg}^{-1}$ respectively; however, for the highest dose of RS-100329 the number declined.

Bladder Only the highest dose $\left(2 \mathrm{mg} \mathrm{kg}^{-1}\right)$ of doxazosin had any effect on distension-induced bladder contractions causing a significant rise in the pressure threshold by $55 \pm 21 \%$ and in the duration of the bladder contractions by $235 \pm 58 \%$. RS- 100329 and RS-513815 at all doses used had no significant effect on distension-induced bladder contractions. However, BMY 7378 caused a significant decrease in the pressure threshold by $35 \pm 8 \%$ at $1 \mathrm{mg} \mathrm{kg}^{-1}$ 
Table 2 Baseline values of urethral pressure, background urethral activity, mean arterial blood pressure (MAP) and heart rate for all experimental groups in urethane anaesthetized male rats. $\mathrm{NMB}=$ neuromuscular blocked

\begin{tabular}{|c|c|c|c|c|c|}
\hline \multirow[b]{2}{*}{$\begin{array}{l}\text { Experimental } \\
\text { group }\end{array}$} & \multicolumn{4}{|c|}{ Baseline values } & \multirow[b]{2}{*}{$\begin{array}{c}\text { Heart rate } \\
\text { (beats } \mathrm{min}^{-1}\end{array}$} \\
\hline & $\mathrm{n}$ & $\begin{array}{l}\text { Urethral pressures } \\
\quad(\mathrm{mmHg})\end{array}$ & $\begin{array}{c}\text { Background } \\
\text { urethral activity } \\
\text { (slow waves } \min ^{-1} \text { ) }\end{array}$ & $\begin{array}{c}M A P \\
(\mathrm{mmHg})\end{array}$ & \\
\hline \multicolumn{6}{|l|}{ Lactic acid } \\
\hline $0.3 \mathrm{ml}$ & 7 & $23.1 \pm 0.7$ & $3.5 \pm 0.2$ & $123 \pm 4$ & $369 \pm 10$ \\
\hline \multicolumn{6}{|l|}{ Doxazosin } \\
\hline $0.1 \mathrm{mg} \mathrm{kg}^{-1}$ & 5 & $17.3 \pm 2.7$ & $4.0 \pm 0.1$ & $106 \pm 5$ & $375 \pm 13$ \\
\hline $0.5 \mathrm{mg} \mathrm{kg}^{-1}$ & 5 & $19.2 \pm 1.4$ & $3.8 \pm 0.2$ & $111 \pm 7$ & $346 \pm 5$ \\
\hline $0.1 \mathrm{mg} \mathrm{kg}^{-1}$ & 5 & $22.2 \pm 0.5$ & $3.5 \pm 0.2$ & $122 \pm 5$ & $353 \pm 14$ \\
\hline $2.0 \mathrm{mg} \mathrm{kg}^{-1}$ & 5 & $25.3 \pm 2.2$ & $4.1 \pm 0.3$ & $122 \pm 5$ & $351 \pm 7$ \\
\hline \multicolumn{6}{|l|}{ RS100329 } \\
\hline $0.01 \mathrm{mg} \mathrm{kg}^{-1}$ & 5 & $24.9 \pm 2.0$ & $3.4 \pm 0.2$ & $119 \pm 6$ & $401 \pm 10$ \\
\hline $0.03 \mathrm{mg} \mathrm{kg}^{-1}$ & 5 & $22.7 \pm 1.3$ & $3.1 \pm 0.2$ & $109 \pm 9$ & $365 \pm 6$ \\
\hline $0.1 \mathrm{mg} \mathrm{kg}^{-1}$ & 5 & $20.3 \pm 2.5$ & $3.6 \pm 0.2$ & $102 \pm 8$ & $390 \pm 16$ \\
\hline $0.3 \mathrm{mg} \mathrm{kg}^{-1}$ & 4 & $19.6 \pm 0.5$ & $3.7 \pm 0.2$ & $109 \pm 4$ & $394 \pm 19$ \\
\hline $1.0 \mathrm{mg} \mathrm{kg}^{-1}$ & 4 & $24.5 \pm 2.4$ & $3.8 \pm 0.2$ & $114 \pm 15$ & $418 \pm 11$ \\
\hline \multicolumn{6}{|l|}{ RS513815 } \\
\hline $0.3 \mathrm{mg} \mathrm{kg}^{-1}$ & 3 & $27.9 \pm 2.4$ & $3.6 \pm 0.4$ & $131 \pm 9$ & $434 \pm 22$ \\
\hline $1.0 \mathrm{mg} \mathrm{kg}^{-1}$ & 3 & $16.3 \pm 1.4$ & $3.2 \pm 0.3$ & $85 \pm 15$ & $397 \pm 13$ \\
\hline $3.0 \mathrm{mg} \mathrm{kg}^{-1}$ & 3 & $18.8 \pm 1.4$ & $3.7 \pm 0.2$ & $105 \pm 10$ & $367 \pm 18$ \\
\hline \multicolumn{6}{|l|}{ BMY 7378} \\
\hline $0.03 \mathrm{mg} \mathrm{kg}^{-1}$ & 5 & $22.0 \pm 0.8$ & $4.1 \pm 0.2$ & $102 \pm 8$ & $364 \pm 12$ \\
\hline $0.1 \mathrm{mg} \mathrm{kg}^{-1}$ & 5 & $17.3 \pm 1.1$ & $3.4 \pm 0.4$ & $111 \pm 4$ & $391 \pm 7$ \\
\hline $0.3 \mathrm{mg} \mathrm{kg}^{-1}$ & 5 & $18.5 \pm 1.1$ & $3.2 \pm 0.3$ & $102 \pm 2$ & $398 \pm 21$ \\
\hline $1.0 \mathrm{mg} \mathrm{kg}^{-1}$ & 5 & $18.3 \pm 0.9$ & $3.7 \pm 0.1$ & $119 \pm 7$ & $394 \pm 7$ \\
\hline \multicolumn{6}{|l|}{ 8-OH-DPAT } \\
\hline $0.03 \mathrm{mg} \mathrm{kg}^{-1}$ & 5 & $19.7 \pm 0.4$ & $4.0 \pm 0.4$ & $101 \pm 5$ & $372 \pm 12$ \\
\hline $0.1 \mathrm{mg} \mathrm{kg}^{-1}$ & 5 & $20.9 \pm 2.0$ & $3.9 \pm 0.2$ & $102 \pm 3$ & $368 \pm 7$ \\
\hline $0.3 \mathrm{mg} \mathrm{kg}^{-1}$ & 6 & $20.1 \pm 0.6$ & $4.0 \pm 0.2$ & $105 \pm 6$ & $373 \pm 9$ \\
\hline \multicolumn{6}{|l|}{ WAY100635 } \\
\hline $0.01 \mathrm{mg} \mathrm{kg}^{-1}$ & 4 & $20.9 \pm 0.5$ & $3.3 \pm 0.3$ & $115 \pm 2$ & $370 \pm 16$ \\
\hline $0.03 \mathrm{mg} \mathrm{kg}^{-1}$ & 4 & $22.2 \pm 1.1$ & $4.2 \pm 0.3$ & $109 \pm 4$ & $406 \pm 9$ \\
\hline $0.1 \mathrm{mg} \mathrm{kg}^{-1}$ & 5 & $21.0 \pm 0.7$ & $3.3 \pm 0.3$ & $107 \pm 6$ & $377 \pm 13$ \\
\hline $0.3 \mathrm{mg} \mathrm{kg}^{-1}$ & 5 & $20.8 \pm 1.6$ & $3.9 \pm 0.4$ & $105 \pm 15$ & $415 \pm 19$ \\
\hline \multicolumn{6}{|l|}{ WAY 100635} \\
\hline $0.01 \mathrm{mg} \mathrm{kg}^{-1}$ & 4 & $25.3 \pm 1.7$ & $3.8 \pm 0.3$ & $107 \pm 9$ & $394 \pm 16$ \\
\hline \multirow{2}{*}{\multicolumn{6}{|c|}{$\begin{array}{l} \pm \mathrm{BMY} 7378 \\
1.0 \mathrm{mg} \mathrm{kg}^{-1}\end{array}$}} \\
\hline & & & & & \\
\hline \multicolumn{6}{|l|}{ Tyramine group } \\
\hline Lactic acid & 2 & $25.8 \pm 0.5$ & $3.3 \pm 0.3$ & $122 \pm 10$ & $405 \pm 14$ \\
\hline Prazosin & 3 & $27.1 \pm 0.4$ & $3.2 \pm 0.4$ & $131 \pm 9$ & $388 \pm 10$ \\
\hline Prazosin plus NMB group & 3 & $22.4 \pm 1.0$ & $3.8 \pm 0.5$ & $124 \pm 3$ & $405 \pm 15$ \\
\hline
\end{tabular}

(Figure 3). The volume threshold was inhibited at all doses, although this was only significant at 0.1 and $1 \mathrm{mg} \mathrm{kg}^{-1}$ $(-70 \pm 13 \%$ and $-66 \pm 16 \%$ respectively).

\section{Effect of the 5-HT $T_{1 A}$ receptor ligands 8-OH-DPAT and $W A Y-100635$ on the micturition reflex}

Traces of the effects of i.v. 8-OH-DPAT and WAY-100635 on the micturition reflex are shown in Figure 2D,E.

Urethra 8-OH-DPAT $\left(0.03-0.3 \mathrm{mg} \mathrm{kg}^{-1} ; n=5-6\right)$ had no effect on reflex-induced contractions, while WAY-100635 (0.03-0.3 mg kg-1; $n=4-5)$ caused a significant inhibition of these contractions by $44 \pm 6 \%$ at the highest dose. $8-\mathrm{OH}$ DPAT also caused a significant increase in baseline urethral pressure at all doses, which was near maximum at the lowest dose of $31 \pm 11 \%$ reaching $41 \pm 11 \%$ by the highest dose. 8OH-DPAT also caused complete inhibition of the spontaneous urethral slow waves at $0.1 \mathrm{mg} \mathrm{kg}^{-1}$. WAY-100635 caused a significant decrease in baseline pressure of $11 \pm 4$ and $14 \pm 4 \%$ at 0.1 and $0.3 \mathrm{mg} \mathrm{kg}^{-1}$ respectively, and at the highest dose caused a significant inhibition of background slow waves by $19 \pm 8 \%$. A comparison of the effects of $8-\mathrm{OH}-$ DPAT and WAY-100635 with that of BMY 7378 on reflexevoked urethral contractions and baseline pressure is shown in Figure 5.

Bladder 8-OH-DPAT had a biphasic effect on the amplitude of reflex-induced contractions, causing a small but significant inhibition at the lowest dose of $-9 \pm 4 \%$ and a potentiation of these contractions at the two highest doses of $23 \pm 6$ and $25 \pm 10 \%$ respectively, although this was only significant at $0.1 \mathrm{mg} \mathrm{kg}^{-1}$ (data not illustrated). In addition, 8-OH-DPAT significantly decreased the pressure threshold to induce a contraction at the two highest doses, reaching a maximum of $-18 \pm 7 \%$ at $0.1 \mathrm{mg} \mathrm{kg}^{-1}$ (Figure 6A). Further, at the highest dose the volume threshold was also significantly reduced by $70 \pm 9 \%$. However, WAY-100635 had no effect on the reflex-induced contractions only increasing the pressure threshold significantly at the two highest doses, reaching a maximum of $153 \pm 43 \%$ (Figure $6 \mathrm{~A}$ ). It should be noted that for the doses of 0.01 and $0.03 \mathrm{mg} \mathrm{kg}^{-1}$ in three experiments 

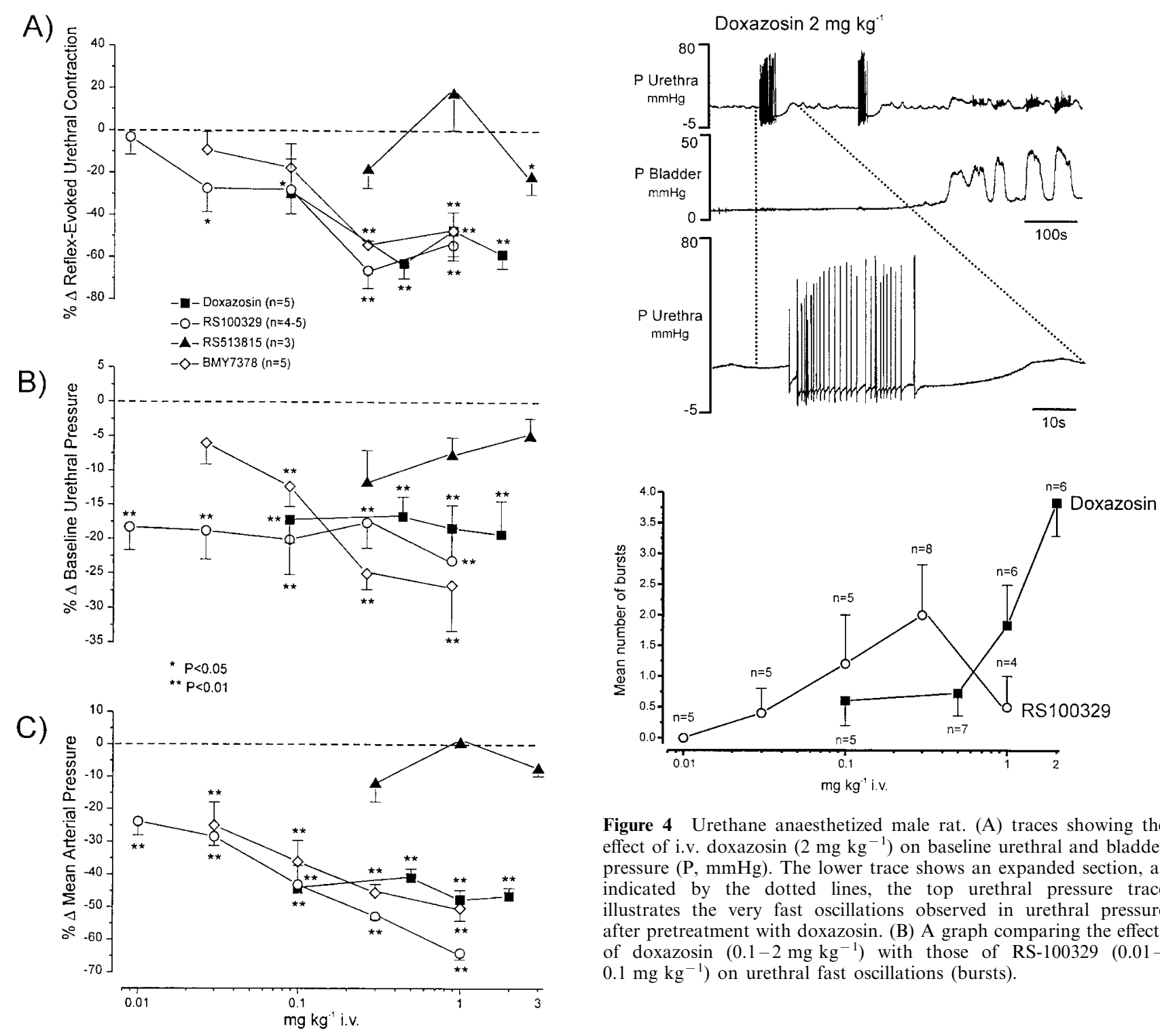

Figure 4 Urethane anaesthetized male rat. (A) traces showing the effect of i.v. doxazosin $\left(2 \mathrm{mg} \mathrm{kg}^{-1}\right)$ on baseline urethral and bladder pressure $(\mathrm{P}, \mathrm{mmHg})$. The lower trace shows an expanded section, as indicated by the dotted lines, the top urethral pressure trace illustrates the very fast oscillations observed in urethral pressure after pretreatment with doxazosin. (B) A graph comparing the effects of doxazosin $\left(0.1-2 \mathrm{mg} \mathrm{kg}^{-1}\right)$ with those of RS-100329 (0.01$0.1 \mathrm{mg} \mathrm{kg}^{-1}$ ) on urethral fast oscillations (bursts).

Figure 3 Urethane anaesthetized male rats: comparison of changes $(\Delta)$ caused by i.v. doxazosin $\left(0.1-2 \mathrm{mg} \mathrm{kg}^{-1}\right)$, RS-100329 (0.01$\left.0.1 \mathrm{mg} \mathrm{kg}^{-1}\right)$, RS-513815 (0.3-3.0 $\left.\mathrm{mg} \mathrm{kg}^{-1}\right)$ and BMY $7378(0.1-$ $1 \mathrm{mg} \mathrm{kg}^{-1}$ ) on (A) intravesical infusion of saline (reflex) evoked urethral contractions, (B) baseline urethral pressure and (C) mean arterial blood pressure. Each point represents the mean value and the vertical bars show s.e.mean. Changes caused by drugs were compared with vehicle controls $(0.04 \mathrm{M}$ lactic acid i.v.) using Student's unpaired $t$-test. $* P<0.05$ and $* * P<0.01$.

in each group, which have not been included in the overall groups for WAY-100635, the saline infusion did not evoke a reflex after WAY-100635, although 10 min later a reflex could be evoked.

\section{Effect of pretreatment with the 5-HT $T_{1 A}$ receptor antagonist WAY-100635 on changes in the micturition reflex induced by $B M Y 7378$}

Urethra Pretreatment with WAY-100635 $(n=4)$ at $0.01 \mathrm{mg} \mathrm{kg}^{-1}$ (i.v.), a dose that did not significantly affect the micturition reflex (see above), did not affect the ability of

BMY $73781 \mathrm{mg} \mathrm{kg}^{-1}$ (i.v.) to completely inhibit background activity, to reduce baseline pressure by $15 \pm 3 \%$ and to inhibit reflex-evoked contractions by $51 \pm 8 \%$.

Bladder Pretreatment with WAY-100635 blocked the ability of BMY 7378 to decrease the pressure threshold (Figure 6B) and the volume threshold from $-66 \pm 16$ to $41 \pm 14 \%$. However, this increase in volume threshold was not significantly different from lactic acid.

\section{Effect of tyramine in the absence and presence of $\alpha$-bungarotoxin}

Tyramine given close arterially $\left(1 \mathrm{mg} \mathrm{kg}^{-1}\right)$ evoked a contraction of the urethra and a rise in heart rate and arterial blood pressure in the absence $(n=5)$ and presence $(n=3)$ of $\alpha$-bungarotoxin. Pretreatment with prazosin $\left(0.3 \mathrm{mg} \mathrm{kg}^{-1}\right)$ in both cases abolished the urethral contraction and attenuated the pressor response evoked by tyramine. In the absence of $\alpha$-bungarotoxin, prazosin evoked spontaneous bursts of high amplitude and frequency oscillations in 


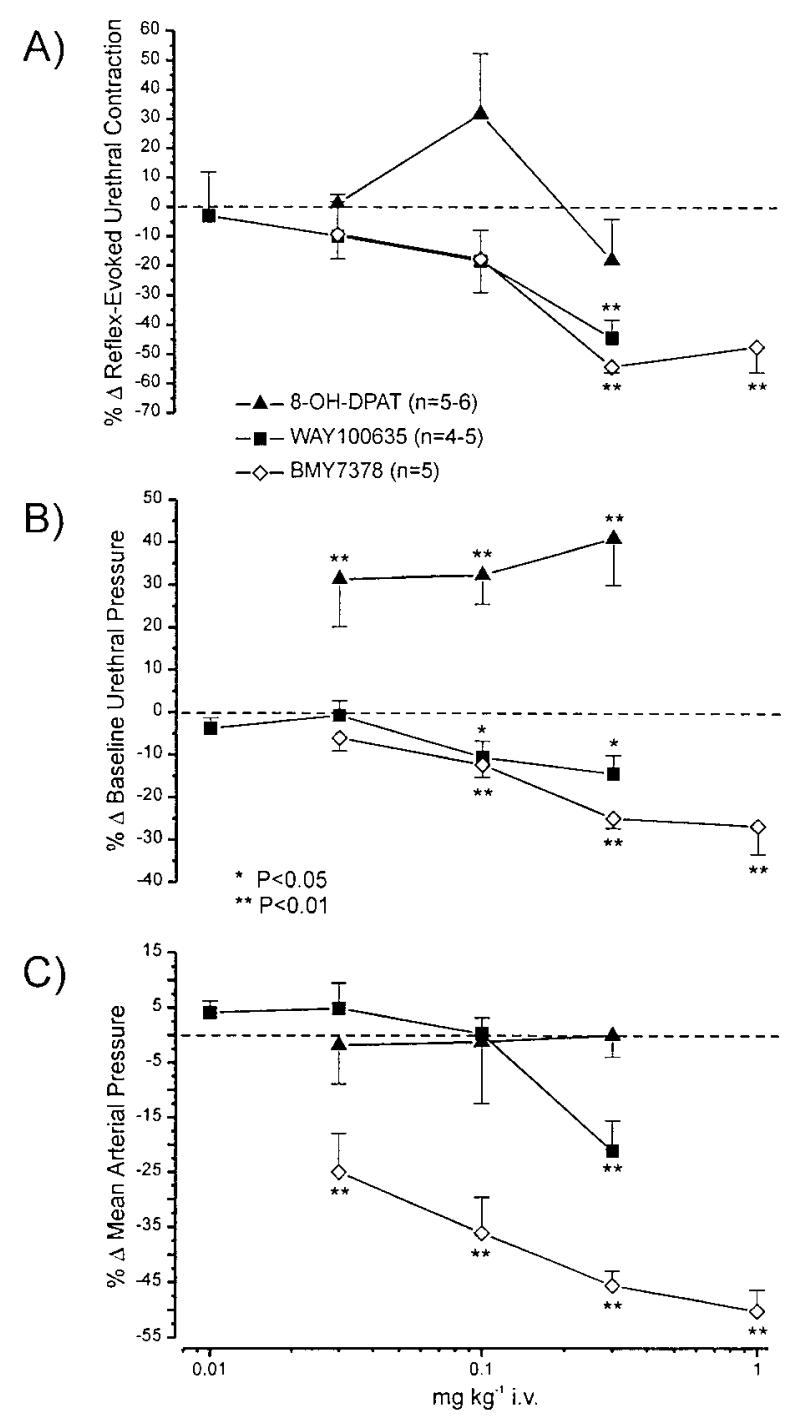

Figure 5 Urethane anaesthetized male rats. Comparison of changes $(\Delta)$ caused by i.v. 8-OH-DPAT $\left(0.03-0.3 \mathrm{mg} \mathrm{kg}^{-1}\right)$, WAY-100635 $\left(0.03-0.3 \mathrm{mg} \mathrm{kg}^{-1}\right)$ and BMY $7378\left(0.1-1 \mathrm{mg} \mathrm{kg}^{-1}\right)$ on (A) intravesical infusion of saline (reflex) evoked urethral contractions, (B) baseline urethral pressure and (C) mean arterial blood pressure. Each point represents the mean value and the vertical bars show s.e.mean. Changes caused by these drugs were compared with vehicle controls $(0.04 \mathrm{M}$ lactic acid i.v.) using Student's unpaired $t$-test. $* P<0.05$ and $* * P<0.01$.

urethral pressure in two out of three animals as observed for doxazosin and RS-100329.

The effect of doxazosin, RS-100329, RS-513815, BMY 7378, 8-OH-DPAT and WAY-100635 on arterial blood pressure and heart rate

Doxazosin $\left(0.1-2 \mathrm{mg} \mathrm{kg}^{-1} ; n=5\right)$ caused a significant fall in mean arterial blood pressure at all doses, which was near maximum by the lowest dose at $-44 \pm 2 \%$ (Figure 3 ). This was associated with no change in heart rate at low doses, but a significant bradycardia of $-14 \pm 4 \%$ by the highest dose. RS-100329 $\left(0.01-1 \mathrm{mg} \mathrm{kg}^{-1} ; n=4-5\right)$ caused a significant dose related fall in mean arterial blood pressure starting at $-24 \pm 4 \%$ and reaching $-64 \pm 2 \%$ by the highest dose
(Figure 3). Again this was associated with no change in heart rate at low doses but at the highest dose a significant bradycardia of $11 \pm 3 \%$ and $16 \pm 1 \%$. RS-513815 (0.3$3 \mathrm{mg} \mathrm{kg}^{-1} ; n=3$ ) had no effect on mean arterial blood pressure or heart rate. Like RS-100329, BMY 7378 (0.03$\left.1 \mathrm{mg} \mathrm{kg}^{-1} ; n=5\right)$ caused a dose related fall in mean arterial blood pressure (Figure 3) reaching a maximum of $50 \pm 4 \%$ and again at the highest two doses this was associated with a bradycardia of $10 \pm 3$ and $18 \pm 3 \%$ respectively. 8-OH-DPAT $\left(0.03-0.3 \mathrm{mg} \mathrm{kg}^{-1} ; n=5-6\right)$, surprisingly failed to have any effect on mean arterial blood pressure or heart rate, while WAY-100635 only caused a fall in mean arterial blood pressure at the highest dose of $21 \pm 6 \%$ and this was not associated with any change in heart rate. Further, the dose of $0.01 \mathrm{mg} \mathrm{kg}^{-1}$ of WAY-100635 failed to affect the hypotension and bradycardia caused by $1 \mathrm{mg} \mathrm{kg}^{-1}$ of BMY 7378 .

\section{Discussion}

These experiments have shown that the $\alpha_{1}$-adrenceptor antagonists doxazosin, RS-100329 and BMY 7378 reduce baseline urethral pressure and inhibit reflex urethral contractions. The selectivity of these compounds towards different $\alpha_{1}$-adrenoceptor subtypes (see Introduction) would indicate that these effects involve the activation of $\alpha_{1 \mathrm{~A}^{-}}$and $\alpha_{1 \mathrm{D}^{-}}$ adrenoceptors. Further, as RS-513815 only attenuates urethral contractions at very high doses this would imply that $\alpha_{1 \mathrm{~B}}$-adrenoceptors do not play a major role in the micturition reflex. However, BMY 7378 differed from the other $\alpha_{1}$-adrenoceptor antagonists in that, at high doses, it causes a reduction in bladder pressure and volume threshold. The selective $5-\mathrm{HT}_{1 \mathrm{~A}}$ receptor agonist $8-\mathrm{OH}-\mathrm{DPAT}$, in the present experiments, also reduced the bladder pressure and volume thresholds. This latter result confirms similar observations made by Lecci et al. (1992) who found that 8OH-DPAT evoked contractions of the bladder when it was filled with a subthreshold volume of saline. The ability of the selective 5-HT $\mathrm{HT}_{1 \mathrm{~A}}$ receptor antagonist to block these effects of BMY 7378 at a dose that did not interfere with the reflex indicates that such actions of BMY 7378 are mediated by 5$\mathrm{HT}_{1 \mathrm{~A}}$ receptors, not $\alpha_{1 \mathrm{D}}$-adrenoceptors. Further, the ability of WAY-100635 at a higher concentration to increase the bladder pressure threshold indicates that $5-\mathrm{HT}_{1 \mathrm{~A}}$ receptors play a major physiological role in the control of the micturition reflex, as well as confirming the recent observations of Testa et al. (1999). Thus, the combined data indicate that $\alpha_{1}$-adrenoceptors mediate contractions of the urethra whilst $5-\mathrm{HT}_{1 \mathrm{~A}}$ receptors regulate bladder activity during micturition. Interestingly, WAY-100635 also attenuated reflex-evoked urethral contractions at these high doses, which could suggest that $5-\mathrm{HT}_{1 \mathrm{~A}}$ receptors are involved in such effects. However, the next receptor family after $5-\mathrm{HT}_{1 \mathrm{~A}}$ receptors that WAY-100635 has affinity for are $\alpha_{1}$-adrenoceptors (Forster et al., 1995). Further, WAY-100635 shows little selectivity between the $\alpha_{1}$-adrenoceptor subtypes (Testa et al., 1999). Thus, as WAY-100635 also causes a fall in arterial blood pressure at the concentration at which it affects urethral contraction (and further as this occurs at a higher dose than that observed for the bladder effects), it is likely that this effect is mediated by blockade of $\alpha_{1}$-adrenoceptors rather than $5-\mathrm{HT}_{1 \mathrm{~A}}$ receptors. 

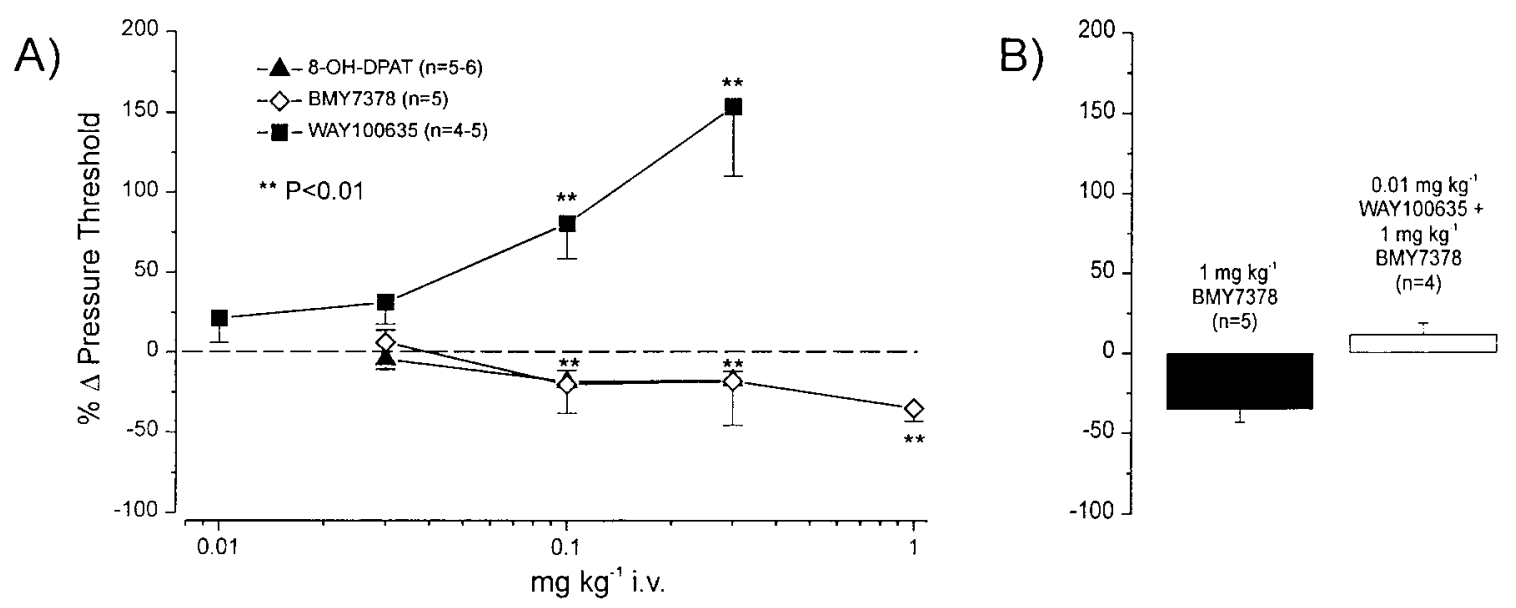

Figure 6 Urethane anaesthetized male rats. (A) Comparison of changes $(\Delta)$, in bladder pressure threshold for intravesical infusion of saline to evoke bladder contractions, caused by i.v. 8-OH-DPAT $\left(0.03-0.3 \mathrm{mg} \mathrm{kg}^{-1}\right)$, WAY-100635 $\left(0.03-0.3 \mathrm{mg} \mathrm{kg} \mathrm{kg}^{-1}\right)$ and BMY $7378\left(0.1-1 \mathrm{mg} \mathrm{kg}^{-1}\right)$. Each point represents the mean value and the vertical bars show s.e.mean. Changes caused by these drugs were compared with vehicle controls $(0.04 \mathrm{M}$ lactic acid i.v.) using Student's unpaired $t$-test. ** $P<0.01$. (B) A comparison of the effect of $1 \mathrm{mg} \mathrm{kg}^{-1}$ of BMY 7378 in the absence and presence of WAY-100635 $\left(0.01 \mathrm{mg} \mathrm{kg}^{-1}\right)$ on changes $(\Delta)$ in bladder pressure threshold.

That RS-100329 and BMY 7378 have similar potencies in causing inhibition of reflex-evoked urethral contractions and the fall in arterial blood pressure suggests that their effects are mainly mediated by $\alpha_{1 D^{-}}$adrenoceptors with some $\alpha_{1 A^{-}}$ adrenoceptor involvement, since both drugs have similar affinities for the $\alpha_{1 \mathrm{D}}$-adrenoceptor. On the rat aorta $\left(\alpha_{1 \mathrm{D}}\right)$ the $\mathrm{pA}_{2}$ for RS-100329 is 7.9 (Williams et al., 1999), while the $\mathrm{pK}_{\mathrm{i}}$ for BMY 7378 is 8.2 (Goetz et al., 1995). At $\alpha_{1 \mathrm{~A}^{-}}$ adrenoceptors, RS-100329 has approximately 1000 fold higher affinity than $\mathrm{BMY} 7378$, the $\mathrm{pA}_{2}$ on the rabbit bladder neck $\left(\alpha_{1 \mathrm{~A}}\right)$ being 9.2 (Williams et al., 1999) while the $\mathrm{pK}_{\mathrm{B}}$ for BMY 7378 is 6.2 (Kava et al., 1998). This is somewhat surprising as contractions of the rat urethra are mediated by $\alpha_{1 \mathrm{~A}}$-adrenoceptors (Chess-Williams et al., 1994). In fact, in the present experiments where tyramine was used to cause the release of noradrenaline from local varicosities, the increase in urethral pressure thus evoked was blocked by prazosin, suggesting that these receptors receive sympathetic innervation. This is further supported by the recent observations that, in anaesthetized male rats in which the prostate had been removed, stimulation of the hypogastric nerve caused an increase in urethral pressure which was blocked by prazosin $\left(0.1 \mathrm{mg} \mathrm{kg}^{-1}\right.$; Kontani \& Shiraoya, 2000). Yet the observation that the micturition reflex evokes contractions of the urethra is unexpected, in that effective micturition requires urethral relaxation. However, in the present experiments urethral pressure measurements were made in the proximal, prostatic urethra, where the longitudinal smooth muscle contracts at the onset of micturition to open the bladder neck (see Kakizaki et al., 1997). However, it is doubtful that changes in the bladder neck are being measured as the cannula is wedged up against this area and would thus be expected to prevent any changes being measured. In this respect, measurements in conscious human subjects have shown that the smooth muscle component of the bladder neck contracts during the initiation of voiding (Yalla \& Resnick, 1997). Interestingly, in female rats, using the above experimental technique urethral relaxations only were observed (Wibberley et al., 1999). It should be noted that this probably reflects anatomical differences in the respective urethras, the male being much longer and kinked, combined with the physical problems of recording pressure at one end of a tube and assuming that it reflects changes along the whole tube. Therefore in males it would be expected that the recording will tend more to reflect changes in the proximal part while in the female there will be a greater chance that the changes measured will be representative of the whole urethra. Further, the contraction of male urethral longitudinal smooth muscle to open the bladder neck at the onset of micturition, as measured in the present experiments, is not mediated by sympathetic but by parasympathetic outflow and blocked by atropine, at least in the rat (Kakizaki et al., 1997). Thus the ability of $\alpha_{1 \mathrm{~A} / \mathrm{D}^{-}}$ adrenoceptors to modify this component of the micturition reflex suggests that during micturition the parasympathetic outflow to this part of the urethra is controlled by a noradrenergic input. The precise site/s at which the noradrenergic input controls this parasympathetic outflow remains to be determined. In this respect, central $\alpha_{1}$ adrenceptors have long been known to be facilitatory in the control of sympathetic outflow to the cardiovascular system (Ramage, 1984; 1986) and to the lower urogenital tract (Gajewski et al., 1984; Ramage \& Wyllie, 1995; Danuser et al., 1995). One site at which these $\alpha_{1}$-adrenoceptor facilitatory receptors may be is in the spinal cord (Yoshimura et al., 1990a;b; Ishizuka et al., 1997; Jeong \& Lee, 2000). However, $\alpha_{1 \mathrm{~A}}$-adrenoceptors are the major subtype that is found in the rat spinal cord (Wada et al., 1996), although the present data indicate that the main $\alpha_{1}$-adrenoceptor subtype that is involved is the $\alpha_{1 \mathrm{D}}$-adrenceptor. It is possible that these $\alpha_{1 D^{-}}$-adrenceptors could be at a different site to the $\alpha_{1 A^{-}}$ adrenoceptors. Another possibility is that the $\alpha_{1}$-adrenceptor could be located prejunctionally (Somogyi et al., 1995) on the cholinergic terminals; however, these facilitatory receptors have been shown to be $\alpha_{1 \mathrm{~A}^{-}}$and not $\alpha_{1 \mathrm{D}^{-}}$-adrenceptors (Széll et al., 2000). It should be pointed out that these data come 
from experiments focusing on the bladder rather than the urethra. Further, in the present experiments, resting urethral tone was decreased in the presence of the antagonists, RS100329 being the most potent with BMY 7378 and doxazosin having a similar potency and RS-513815 having little effect, indicating that this effect is predominantly mediated by $\alpha_{1 \mathrm{~A}^{-}}$ adrenoceptors and that the maintenance of background urethral tone is, to a degree, under sympathetic control. Interestingly, the present data indicate that there is little dose relationship to these effects. It could be argued that the doses used are maximal; however, Martin et al. (1997) using lower doses of doxazosin in male rats anaesthetized with pentobarbitone showed a similar effect. The failure to observe a dose response may be related to the method of recording changes in urethral tension in the present experiments and in those of Martin et al. (1997); however, the exact mechanism remains to be determined. The present data suggest that this background tone is mainly mediated by $\alpha_{1 \mathrm{~A}}$-adrenoceptors; it is, therefore, surprising that 5-methyl-urapidil, which is selective for $\alpha_{1 \mathrm{~A}}$-adrenoceptors, failed to affect background urethral tone (Martin et al., 1997). However, 5-methylurapidil is also a $5-\mathrm{HT}_{1 \mathrm{~A}}$ receptor agonist (Gross et al., 1990) and, in the present experiments, the $5-\mathrm{HT}_{1 \mathrm{~A}}$ receptor agonist 8-OH-DPAT caused an increase in baseline urethral tone. Thus, the ability of 5-methyl-urapidil to have opposing actions on baseline urethral tone may explain the lack of effect observed by Martin et al. (1997). Such an interaction could also explain why the effects of BMY 7378 on urethral tone seem to be dose related in the present experiments. Further, in the present experiments RS-100329, doxazosin and prazosin but not BMY 7378 or RS-513815 caused the appearance of bursts of fast high amplitude oscillation in urethral pressure. Such bursts of high frequency oscillation in urethral pressure are observed during bladder distension, although of a much smaller amplitude (Figures 2 and 4). These small amplitude oscillations in urethral pressure during simulated micturition are considered to be due to changes in the activity in the external (striated muscle) urethral sphincter (see Kakizaki et al., 1997). However, exactly what these very high amplitude oscillations are remains to be determined, although they probably represent changes in the external sphincter activity and such changes could be related to ejaculation. However, the present data suggest that whatever these high amplitude oscillations represent they are under tonic $\alpha_{1 \mathrm{~A}}$-adrenoceptor inhibitory control.

In the present experiments bladder distension-induced contractions were unaffected by RS-100329 and RS-513815 indicating that, in the rat, $\alpha_{1 \mathrm{~A}}$ and $\alpha_{1 \mathrm{~B}}$-adrenoceptors play little role in the control of bladder reflex contractions. This may seem somewhat surprising due to the evidence (see above) indicating that $\alpha_{1}$-adrenoceptors play a facilitatory role in the control of sympathetic supply to the bladder. BMY 7378 did decrease bladder threshold to initiate a reflex but, as this was similar to the effect observed with 8-OHDPAT and could be blocked by pre-treatment with WAY100635 , this effect is due to activation of $5-\mathrm{HT}_{1 \mathrm{~A}}$ receptors not $\alpha_{1 \mathrm{D}}$-adrenoceptors confirming the data of Lecci et al. (1992) and Testa et al. (1999). Further the ability of WAY100635 to cause a dose related increase in bladder pressure threshold in anaesthetized and conscious rats (Testa et al., 1999) indicates that $5-\mathrm{HT}_{1 \mathrm{~A}}$ receptors play a major physiological role in the control of micturition. Interestingly, in some of the present experiments, WAY-100635 was found to completely abolish the bladder reflex and this is consistent with i.c.v. application of WAY-100635 in other reports (see Testa et al., 1999; Kakizaki et al., 1998). Overall the published data (Lecci et al., 1992; Testa et al., 1999; Kakizaki et al., 1998) indicate that these $5-\mathrm{HT}_{1 \mathrm{~A}}$ receptors are located supra-spinally and spinally. These data again support the view (Ramage, 2000) that $5-\mathrm{HT}_{1 \mathrm{~A}}$ receptors play an important role in the reflex activation of parasympathetic outflow. However, as the urethral-evoked contractions (see above) are mediated by parasympathetic outflow the question arises as to why they seem to be unaffected by interference with $5-\mathrm{HT}_{1 \mathrm{~A}}$ receptors. The argument presented above suggests that the effects of WAY-100635 in inhibiting urethral-evoked reflex contraction are due to $\alpha_{1}$-adrenoceptor blockade as, at these high doses, WAY-100635 also caused decreases in baseline urethral pressure and arterial blood pressure indicative of $\alpha_{1}$-adrenoceptor blockade. However, 8OH-DPAT had a tendency to increase reflex-evoked urethral contractions. Thus, although in the present study this parasympathetic reflex has been demonstrated to be regulated by $\alpha_{1}$-adrenoceptors, the problem of the overlap between $\alpha_{1}$ adrenoceptors and $5-\mathrm{HT}_{1 \mathrm{~A}}$ receptors in the selectivity of the ligands used makes it difficult to absolutely determine if there is a role for $5-\mathrm{HT}_{1 \mathrm{~A}}$ receptors in the control of this particular system. Further, the overall role of sympathetic innervation to the urethra in the regulation of this organ also remains to be determined.

The fact that both RS-100329 and BMY 7378 have a similar potency in lowering arterial pressure suggests that the maintenance of $\alpha_{1}$-adrenoceptor-mediated sympathetic vasoconstrictor tone is mediated by both $\alpha_{1 \mathrm{~A}^{-}}$and $\alpha_{1 \mathrm{D}^{-}}$ adrenoceptors and a comparison of the potency differences between the antagonists at these receptors (see above) suggests that $\alpha_{1 \mathrm{D}}$-adrenoceptors are predominant in this effect. In this respect $\alpha_{1 \mathrm{D}}$-adrenoceptors have been shown to be involved in the contraction of rat aorta, mesenteric and pulmonary artery (Hussain \& Marshall, 1997; Williams et al., 1999), while $\alpha_{1 \mathrm{~A}}$-adrenoceptors have been shown to mediate contraction of the rat caudal artery (Lachnit et al., 1997). However, the failure of RS-513815 to affect arterial pressure indicates that $\alpha_{1 \mathrm{~B}}$-adrenoceptors, at least in the present model of urethane anaesthetized rats, play no role in the maintenance of baseline arterial blood pressure. Interestingly, at high doses, RS-100329 caused a profound fall in arterial blood pressure and this is greater than that observed for high doses of doxazosin, implying that RS-100329 is interfering with a mechanism other than $\alpha_{1}$-adrenoceptors that is also important in the maintenance of arterial blood pressure. In addition, and somewhat surprisingly, 8-OH-DPAT failed to cause a fall in arterial blood pressure in this model. However, in the rat, activation of central 5- $\mathrm{HT}_{1 \mathrm{~A}}$ receptors can evoke both sympathoinhibition (Gradin et al., 1985; Fozard et al., 1987) and excitation (Anderson et al., 1995; 1996).

In conclusion, the present data indicate that, in the male rat, the reflex-evoked parasympathetic mediated contractions of the urethra are under $\alpha_{1 \mathrm{~A}^{-}}$and $\alpha_{1 \mathrm{D}^{-}}$-adrenoceptor regulation; however, no role for $\alpha_{1 \mathrm{~B}}$-adrenoceptors could be identified. The proportion of each subtype $\alpha_{1 \mathrm{~A}^{-}}$and $\alpha_{1 \mathrm{D}}$ involved is difficult to determine, although the data favour a dominant role for $\alpha_{1 \mathrm{D}}$-adrenoceptors. The precise site/s at which this noradrenergic pathway controls the reflex-evoked 
contraction remains to be determined. Interestingly, at least in the male urethane anaesthetized rat, these receptors play no overt role in the control of bladder, although the present and other published data (see above) indicate that 5hydroxytryptaminergic input activating $5-\mathrm{HT}_{1 \mathrm{~A}}$ receptors is important in the induction of volume distension-induced reflex contractions of the bladder. Again the precise site/s for this action remain to be determined. Although the present data do not favour a role for this pathway in the control of reflex urethral contraction, the ability of WAY-100635 to block $\alpha_{1}$-adrenoceptors makes this difficult to completely rule out.

This work was supported by a grant from Roche Biosciences, Palo Alto to A.G. Ramage. We also wish to thank Mr S. Wilkinson for technical assistance and Chet de Groat for advising us on the technique while he was visiting the Autonomic Neuroscience Institute at the Royal Free Campus. We are also grateful to Dr A. Wibberley for drawing Figure 1 .

\section{References}

ANDERSON, K.E. (1993). Pharmacology of lower urinary tract smooth muscles and penile erectile tissues. Pharmacol. Rev., 45, $253-308$

ANDERSON, I.K., MARTIN, G.R. \& RAMAGE, A.G. (1995). Evidence that i.c.v. administration of 5-HT causes sympathoexcitation through activation of $5-\mathrm{HT}_{1 \mathrm{~A}}$ receptors and vasopressin release through activation of $5-\mathrm{HT}_{2 / 1 \mathrm{C}}$ receptors in anaesthetized rats. Br. J. Pharmacol., 107, 1020-1028.

ANDERSON, I.K., RAMAGE, A.G. \& GARDINER, S.M. (1996) Cardiovascular effects of i.c.v. administration of serotonin and DP-5-CT in conscious Long-Evans and Brattleboro rats. Am. J. Physiol., 271, R455-R463.

BRUNE, M.E., KATWALA, S.P., MILICIC, I., BUCKNER, S.A., IRELAND, L.M., KERWIN JR, J.F. \& HANCOCK, A.A. (1996). Effects of selective and nonselective alpha-1-adrenoceptor antagonists on intraurethral and arterial pressures in intact conscious dogs. Pharmacology, 53, 356-368.

CHAPPLE, C.R. (1996). Selective $\alpha_{1}$-adrenoceptor antagonists in benign prostatic hyperplasia: rationale and clinical experience. Eur. Urol., 29, 129-144.

CHESS-WILliAMS, R., ASTON, N. \& COULDWELL, C. (1994). $\alpha_{1 \mathrm{~A}}$ adrenoceptors subtype mediates contraction of the rat urethra. J. Auton. Pharmacol., 14, 375-381.

DANUSER, H., BEMIS, K. \& THOR, K.B. (1995). Pharmacological analysis of the noradrenergic control of central sympathetic and somatic reflexes controlling the lower urinary tract in the anesthetized cat. J. Pharmacol. Exp. Ther., 274, 820-825.

DE GROAT, W.C., DOUGLAS, J.W., GLASS, J., SIMMONDS, W., WEIMER, B., MORGAN, C. \& NADELHAFT, I. (1979). Neural control of the urinary bladder and large intestine. In: Integrative Functions of the autonomic Nervous System. ed. Brooks, C.M., Koizumi, K. \& Sato, A. pp. 50-67. Tokyo: Tokyo Univ. Press.

DE GROAT, W.C., YOSHIYAMA, M., RAMAGE, A.G., YAMAMOTO, T \& SOMOGYI, G.T. (1999). Modulation of voiding and storage reflexes by activation of $\alpha_{1}$-adrenoceptors. Eur. Urol., 36 (Suppl. 1): $68-73$.

ESPEY, M.J., DU, H.J. \& DOWNIE, J.W. (1998). Serotonergic modulation of spinal ascending activity and sacral reflex activity evoked by pelvic nerve stimulation in cats. Brain Res., 798, $101-$ 108.

FORSTER, E.A., CLIFFE, I.A., BILL, D.J., DOVER, G.M., JONES, D., REILLY, Y.\& FLETCHER, A. (1995). A pharmacological profile of the selective silent $5-\mathrm{HT}_{1 \mathrm{~A}}$ receptor antagonist, WAY-100635. Eur. J. Pharmacol., 281, $81-88$.

FOZARD, J.R., MIR, A.K. \& MIDDLEMISS, D.N. (1987). Cardiovascular response to 8-hydroxy-2-(di-n-propylamino) tetralin (8OH-DPAT): Site of action and pharmacological analysis. J. Cardiovasc. Pharmacol., 9, 328-347.

GAJEWSKI, J., DOWNIE, J.W. \& AWAD, S.A. (1984). Experimental evidence for a central nervous system site of action in the effect of alpha-adrenergic blockers on the external urinary sphincter. J. Urol., 133, $403-409$.

GOETZ, A.S., KING, H.K., WARD, S.D., TRUE, T.A., RIMELE, T.J. \& SAUSSY, JR. D.L. (1995). BMY 7378 is a selective antagonist of the D subtype of $\alpha_{1}$-adrenoceptors. Eur. J. Pharmacol., 272, R5R6.
GRAdin, K., PETtERSSON, A., HEDNER, T. \& PERSSON, B. (1985). Acute administration of 8-hydroxy-2-(di-n-propyl-amino) tetralin (8-OH-DPAT), a selective 5-HT-receptor agonist, causes a biphasic blood pressure response and a bradycardia in the normotensive Sprague-Dawley rat and in the spontaneously hypertensive rat. J. Neural Transmission, 62, 305-319.

GROSS, G, SCHÜTLER, K., XIN, X. \& HANFT, G. (1990). Urapidil analogues are potent ligands of the $5-\mathrm{HT}_{1 \mathrm{~A}}$ receptor. $J$. Cardiovasc. Pharmacol., 15(Suppl. 7): S8-S16.

Guilmard, C., AUGuet, M. \& CHABRIER, P.E. (1996). Pharmacological characterization of alpha ${ }_{1}$-adrenoceptor subtype mediating regulation of arterial pressure and urethral perfusion pressure in the anaesthetized rat. J. Auton. Pharmacol., 16, 197-203.

HIEBLE, J.P., BYLUND, D.B., CLARKE, D.E., EIKENBURG, D.C., LANGER, S.Z., LEFKOWITZ, R.J., MINNEMAN, K.P. \& RUFFOLO JR., R.R. (1995). International Union of Pharmacology. X. Recommendation for nomenclature of $\alpha_{1}$-adrenoceptors: consensus update. Pharmacol. Rev., 47, 267-270.

HUSSAIN, M.B. \& MARSHALL, I. (1997). Characterization of $\alpha_{1}$ adrenoceptor subtypes mediating contractions to phenylephrine in rat thoracic aorta, mesenteric artery and pulmonary artery. Br. J. Pharmacol., 122, 849-858.

IMAGAWA, J., AKIMA, M. \& SAKAI, K. (1989a). Functional evaluation of sympathetically mediated responses in in vivo lower urinary tract of dogs. J. Pharmacol. Meth., 22, 103-111.

IMAGAWA, J., AKIMA, M. \& SAKAI, K. (1989b). In vivo experiments for the evaluation of $\alpha_{1}$-adrenoceptor antagonistic effects of SGB-1534 on canine urethra. Eur. J. Pharmacol., 167, 167-172.

ISHIZUKA, O., PANDITA, R.K., MATTIASSON, A., STEERS, W.D. \& ANDERSSON, K.-E. (1997). Stimulation of bladder activity by volume, L-dopa and capsaicin in normal conscious rats-effects of spinal $\alpha_{1}$-adrenoceptor blockade. Naunyn Schmiedebergs Arch. Pharmacol., 355, 787-793.

JEONG, M.S. \& LEE, J.G. (2000). The role of spinal and peripheral $\alpha_{1}$ and $\alpha_{2}$-adrenoceptors on bladder activity induced by bladder distension in anaesthetized rat. Br. J. Urol. Int., 85, 925-931.

JØNLER, M., RIEHMANN, M. \& BRUSKEWITZ, R.C. (1994). Benign prostatic hyperplasia: current pharmacological treatment. Drugs, 47, $66-81$.

KAKIZAKI, H., FRASER, M.O. \& DE GROAT, W.C. (1997). Reflex pathways controlling urethral striated and smooth muscle function in the male rat. Am. J. Physiol., 272, R1647-R1656.

KAKIZAKI, H., KOYANAGI, T., YOSHIYAMA, M. \& DE GROAT, W.C. (1998). Effects of 5-HT $1 \mathrm{~A}$ antagonist on the micturition reflex pathway in the rat. J. Urol., 159 (Suppl. 5): 80.

KAVA, M.S., BLUE, JR., D.R., VIMONT, R.L., CLARKE, D.E. \& FORD, A.P.D.W. (1998). $\alpha_{1 \mathrm{~L}}$-adrenoceptor mediation of smooth muscle contraction in rabbit bladder neck: a model for lower urinary tract tissues of man. Br. J. Pharmacol., 123, 1359-1366.

KENNY, B.A., NAYLOR, A.M., CARTER, A.J., READ, A.M., GREENGRASS, P.M. \& WYLliE, M.G. (1994). Effect of alpha ${ }_{1}^{-}$ adrenoceptor antagonists on prostatic pressure and blood pressure in the anaesthetized dog. Urology, 44, 52-57. 
KLEVMARK, B. (1974). Motility of the urinary bladder in cats during filling at physiological rates. I. Intravesical pressure patterns studied by a new method of cystometry. Acta. Physiol. Scand., 90, $565-577$.

KONTANI, H. \& SHIRAOYA, C. (2000). Sex differences in urethral pressure response to electrical stimulation of the hypogastric nerves in rats. J. Urol., 163, $1364-1368$.

LACHNIT, W.G., TRAN, A.M., CLARKE, D.E. \& FORD, A.P.D.W. (1997). Pharmacological characterization of an $\alpha_{1 \mathrm{~A}}$-adrenoceptor mediating contractile responses to noradrenaline in isolated caudal artery of rat. Br. J. Pharmacol., 120, 819-826.

LECCI, A., GIUliani, S., SANTICIOLI, P. \& MAGGI, C.A. (1992). Involvement of 5-hydroxytryptamine ${ }_{1 \mathrm{~A}}$ receptors in the modulation of micturition reflexes in the anesthetized rat. J. Pharmacol. Exp. Ther., 262, $181-189$.

MAGGI, C.A., SANTICIOLI, P. \& MELI, A. (1986). The nonstop transvesical cystometrogram in urethane-anesthetized rats: a simple procedure for quantitative studies on the various phases of urinary bladder voiding cycle. J. Pharmacol. Meth., 15, 157-167.

MARTIN, D., JAMMES, D. \& ANGEL, I. (1995). Effects of alfuzosin on urethral and blood pressures in conscious male rats. Life Sci., 25, $387-391$.

MARTiN, D.J., LLUEL, P., GUILlot, E., COSTE, A., JAMMES, D. \& ANGEL, I. (1997). Comparative alpha-1 adrenoceptor subtype selectivity and functional uroselectivity of alpha-1 adrenoceptor antagonists. J. Pharmacol. Exp. Ther., 282, 228-235.

MCMAHON, S.B. \& SPILLANE, K. (1982). Brain stem influences on the parasympathetic supply to the urinary bladder of the cat. Brain Res., 234, $237-249$.

MIDDLEMISS, D.N. \& FOZARD, J.R. (1983). 8-hydroxy-2-(di-npropylamino) tetralin discriminates between subtypes of the 5$\mathrm{HT}_{1}$ recognition site. Eur. J. Pharmacol., 90, 151-153.

MORRISON, J.F.B. \& SPILLANE, K. (1982). Characterization of the raphe-spinal pathway which mediates inhibition of the micturition reflex in the cat. J. Physiol., 330, 24P-25P.

NISHIMATSU, H., MORIYAMA, N., HAMADA, K., UKAI, Y., YAMAZAKI, S., KAMEYAMA, S., KONNO, N., ISHIDA, Y., ISHII, Y., MURAYAMA, T. \& KITAMURA, T. (1999). Contractile responses to $\alpha_{1}$-adrenoceptor agonists in isolated human male and female urethra. Br. J. Urol. Int., 84, 515-530.

RAMAGE, A.G. (1984). The effect of prazosin, indoramin and phentolamine on sympathetic nerve activity. Eur. J. Pharmacol., 106, $507-513$.

RAMAGE, A.G. (1986). A comparison of the effects of doxazosin and alfuzosin with those of urapidil on preganglionic sympathetic nerve activity in anaesthetised cats. Eur. J. Pharmacol., 129, $307-314$.

RAMAGE, A.G. (2000). Central 5- $\mathrm{HT}_{1 \mathrm{~A}}$ receptors and vagal tone to the airways. TiPS, 21, 201-202.

RAMAGE, A.G. \& WYLLIE, M.G. (1995). A comparison of the effects of doxazosin and terazosin on the spontaneous sympathetic drive to the bladder and related organs in anaesthetized cats. Eur. J. Pharmacol., 294, 645-650.

SOMOGYI, G.T., TANOWITZ, M. \& DE GROAT, W.C. (1995). Prejunctional facilitatory $\alpha_{1}$-adrenoceptors in the rat urinary bladder. Br. J. Pharmacol., 114, 1710-1716.
SNOWBALL, R.K., WILLIAMS, T.J., FORD, A.P.D.W. \& RAMAGE, A.G. (1999). The role of $5-\mathrm{HT}_{1 \mathrm{~A}}$ receptors and $\alpha_{1}$-adrenoceptors in the control of the "micturition reflex" in the anaesthetized male rat. Br. J. Pharmacol., 128, 228P.

SNOWBALL, R.K., WILLIAMS, T.J., FORD, A.P.D.W. \& RAMAGE, A.G. (2000). Investigation of the role of $\alpha_{1 \mathrm{~A}^{-}}$and $\alpha_{1 \mathrm{D}^{-}}$ adrenoceptors in the control of the "micturition reflex" in the anaesthetized male rat. Br. J. Pharmacol., 129, 35P.

SUZUKI, Y., KANADA, A., OKAYA, Y. \& AISAKA, K. (2000). Effect of JTH-601, a novel $\alpha_{1}$-adrenoceptor antagonist, on prostate function in dogs. Eur. J. Pharmacol., 394, 123-130.

SZÉLL, E.A., YAMAMOTO, T., DE GROAT, W.C. \& SOMOGYI, G.T. (2000). Smooth muscle and parasympathetic nerve terminals in the rat urinary bladder have different subtypes of $\alpha_{1}$-adrenoceptors. Br. J. Pharmacol., 130, $1685-1691$.

TANIGUCHI, N., HAMADA, K., OGASAWARA, T., UKAI, Y., YOSHIKUNI, Y. \& KIMURA, K. (1996). NS-49, an $\alpha_{1}$-adrenoceptor agonist, selectively increases intraurethral pressure in dogs. Eur. J. Pharmacol., 318, 117-122.

TESTA, R., GUARNERI, L., POGGESI, E., ANGEliCO, P., VELASCO, C., IBBA, M., CILIA, A., MOTTA, G., RIVA, C. \& LEONARDI, A. (1999). Effect of several 5-hydroxytryptamine ${ }_{1 \mathrm{~A}}$ receptor ligands on the micturition reflex in rats: comparison with WAY 100635. J. Pharmacol. Exp. Ther., 290, $1258-1269$.

WADA, T., OTSU, T., HASEGAWA, Y., MIZUCHI, A. \& ONO, H. (1996). Characterization of $\alpha_{1}$-adrenoceptor subtypes in rat spinal cord. Eur. J. Pharmacol., 312, 263-266.

WIBBERLEY, A. (2001). The pharmacology of the autonomic control of the female rat urethra: relevance to micturition. University of London. PhD Thesis.

WIBBERLEY, A., NUNN, P.A., NAYLOR, A.M. \& RAMAGE, A.G. (1999). The role of nitric oxide and cGMP in reflex- and DMPPevoked changes in bladder and urethral pressures in the anaesthetised rat. Br. J. Pharmacol., 128, 225P.

WILLIAMS, T.J., BLUE, D.R., DANIELS, D.V., DAVIS, B., ELWORTHY, T., GEVER, J.R., KAVA, M.S., MORGANS, D., PADILLA, F., TASSA, S., VIMONT, R.L., CHAPPLE, C.R., CHESS-WILLIAMS, R., EGLEN, R.M., CLARKE, D.E. \& FORD, A.P.D.W. (1999). In vitro $\alpha_{1}$-adrenoceptor pharmacology of Ro 70-0004 and RS100329, novel $\alpha_{1 \mathrm{~A}}$-adrenoceptor selective antagonists. $\mathrm{Br} . J$. Pharmacol., 127, 252-258.

YALLA, S.V. \& RESNICK, N.M. (1997). Initiation of voiding in humans: the nature and temporal relationship of urethral sphincter responses. J. Urol., 157, 590-595.

YOCCA, F.D., HYSLOP, D.K., SMITH, D.W. \& MAAYANI, S. (1987). BMY 7378, a buspirone analog with high affinity, selectivity and low intrinsic activity at the $5-\mathrm{HT}_{1 \mathrm{~A}}$ receptor in rat and guinea-pig hippocampal membranes. Eur. J. Pharmacol., 137, 293 - 294.

YOSHIMURA, N., SASA, M., YOSHIDA, O. \& TAKAORI, S. (1990a). Mediation of micturition reflex by central norepinephrine from the locus coeruleus in the cat. J. Urol., 143, 840-843.

YOSHIMURA, N., SASA, M., YOSHIDA, O. \& TAKAORI, S. (1990b). $\alpha_{1-}$ adrenergic receptor-mediated excitation from the locus coeruleus of the sacral parasympathetic preganglionic neuron. Life Sci., 47, $789-797$.
(Received December 13, 2000 Revised February 19, 2001 Accepted February 19, 2001) 